\title{
Ice jam flood risks on the rivers of the Baikal Basin
}

\author{
Tatyana Borisova* \\ Baikal Institute of Nature Management SB RAS, Sakhyanovoy 6, 670047, Ulan-Ude, Russia
}

\begin{abstract}
The article presents the results of analysis and assessment of risks related to ice jams on the rivers of the Baikal Lake Basin. It also proposes the recommendations for mitigation and rational development of coastal areas. Data on catastrophic ice jam floods for more than 100 years is presented, the factors of their formation and mechanism of their movement are considered. On the basis of official statistics from expedition surveys, potentially dangerous jamming areas have been identified, and the repeatability and extent of floods have been calculated. With the help of ArcGIS package the scale of possible flooding was determined, which allowed to reveal the list of economic objects within the damage area. Specific indicators have been used to calculate the expected damage to territories, facilities and population from the flood hazard. Analysis and assessment of economic risk from the floods on the Selenga River are given. Measures to minimize risks of negative impact of floods are proposed.
\end{abstract}

\section{Introduction}

Ice phenomena in the rivers of the Baikal Basin are related to the formation of ice built ups, jams and dams, which lead to rising water levels and flooding of economically important territories.

In general, the Selenga River has a number of natural (physical and geographical) predetermining factors and is classified as a river with a high probability of occurrence of jamming phenomena. Features of water and ice regime at favorable weather conditions, and also the channel obstacles caused by morphometric, hydrographic or anthropogenic factors play a significant role in the occurrence of these phenomena [1].

On the territory of Russia the Selenga river flows strictly from the south to the north along the open steppe plain and hilly territory. The valley is variable from narrowed Vshaped sections splitting mountain ridges to well developed box-shaped sections with floodplain multiple arms and braid bar river bed evolution. The main tributaries are the Dzhida river, running from west to east and flowing from the left, and the Chikoi, Khilok, Uda rivers, which have southwestern, western direction, but in the lower reaches Chikoi and Khilok change direction to the north. The rivers are characterised as mountain mountain-plain type with significant slopes and fast streamflow $[2,3]$.

\footnotetext{
* Corresponding author: tabor@binm.ru
} 
The formation of ice regime takes place in the conditions of sharply continental climate with characteristic low winter air temperatures. The first manifestations of ice processes are observed in mid-October in the forms of shuga, ravines and lard, gradually freezing, they form the autumn ice drift, and as a result, on some parts of the riverbeds the ice dams lead to the rise of water levels. However, according to statistics, they are usually not of catastrophic nature. The beginning of freeze-up can be traced from north to south on average from 3-18 November. Duration of ice cover period is from 158 to 175 days. The maximum ice thickness averaged for more than 10 years is $110-120 \mathrm{~cm}[2,3]$.

The break-up of ice in the river starts from the southern part of the basin after the average daily temperature passes over zero. Lagging of ice break up dates along the Selenga River is up to 5-10 days. Thus, according to the statistics data, the date of river ice break-up on the border with Mongolia (hydrological gauge Selenga-Naushki) is recorded on April 19 (from April 10 to 26), downstream (Ulan-Ude) - April 23 and in the delta April 26. The average duration of ice drift is up to 10 days. In the northern part of the basin (middle and lower reaches of the Selenga River) and less frequently in some parts of its main tributaries, the period of ice drift is characterized by ice jams and, consequently, by water level rises. More than 17 potentially hazardous areas are registered, causing water level rises at sections of natural channel features, 6 of which are in the locations of anthropogenic constraint by railway and road bridges $[3,4]$.

Ice jam floods on the Selenga River are rather serious danger for life activity and can cause significant social and economic damage. The purpose of this study is to assess the possible negative consequences of ice jams formation and develop proposals for risk reduction.

\section{Data and research methods}

The background information for the study of ice jam floods was provided by long-term data of maximum levels for the period of spring ice drift since 1934, archive and reference data on the intensity of water rise and fall, duration of high-water marks stands. Reference materials on arrangement of buildings, constructions, objects of infrastructure of industrial and household objects, population size in zones of damage were used in the study. In the course of work statistical methods of information processing by means of GIS technologies were applied $[5,6]$.

Methodological methods for calculating risk indicators are based on hazard indices (repeatability, intensity, area of flooding of developed territories), which allow to determine physical risk or damage of the territory, economic objects, and population (in physical quantities), which is the basis for calculating economic risk [7].

Expected economic damage is defined for the long term as possible (probable) damage from a single event in the state of social and economic development of the district in the absence of protective measures. Damage calculations are performed according to the Methodology of Probabilistic Damage Assessment from Harmful Impact of Water and Assessment of Effectiveness of Preventive Water Management Measures Implementation [8]. Economic risk is defined as possible damage for population and economy from flooding per year.

\section{Results and discussion}

Analysis of archive materials, long-term hydrological data, and results of reconnaissance survey show that hazardous ice jamming phenomena are observed in the rivers of the basin: the Selenga river itself, the Khilok river, less frequent in the lower reaches of the Chikoi 
river (Chikoi-Povorot hydrological gauge). Over the past century, a number of extreme water level rises have been recorded due to ice jams and flooding of coastal areas. Thus, according to B.D. Zaikov [3, p.57] the flooding on the Khilok River occurred on April 24, 1910 and was caused by ice jams. Water level rose by $2.8 \mathrm{~m}$, and all villages adjacent to the railway were flooded. According to the surveys of old residents, catastrophic ice jam flood occurred on April 25, 1962 at the Selenga River near the village of Reid. Residential houses of the settlement were flooded. Water in houses reached the level of more than $0.5-0.7 \mathrm{~m}$. After this event most of the settlement was moved higher from the shoreline (Ostrog village). Catastrophic ice jam floods occurred in the area of Mostovaya Passage in 1974 and 1977 with intensity higher than that of 1936 and 1973 [3, 4].

According to the statistics of maximum levels of the spring ice drift period since 1934, periodic floods as a result of ice jamming are observed on the Selenga River in its lower reaches, the highest levels of which were registered in 1941, 1949, 1968, 1969, 1974, 1977, 2001. The maximum level was $613 \mathrm{~cm}$ (1977) with a critical level of 520-550 cm (gauge datum $486.07 \mathrm{~m} \mathrm{BS}$ ) [4].

On the basis of recurrence calculations for the origin of past floods it was determined that the share of ice jam floods on the Selenga River is $24 \%$ and on the Khilok river is $28 \%$ (Fig. 1).
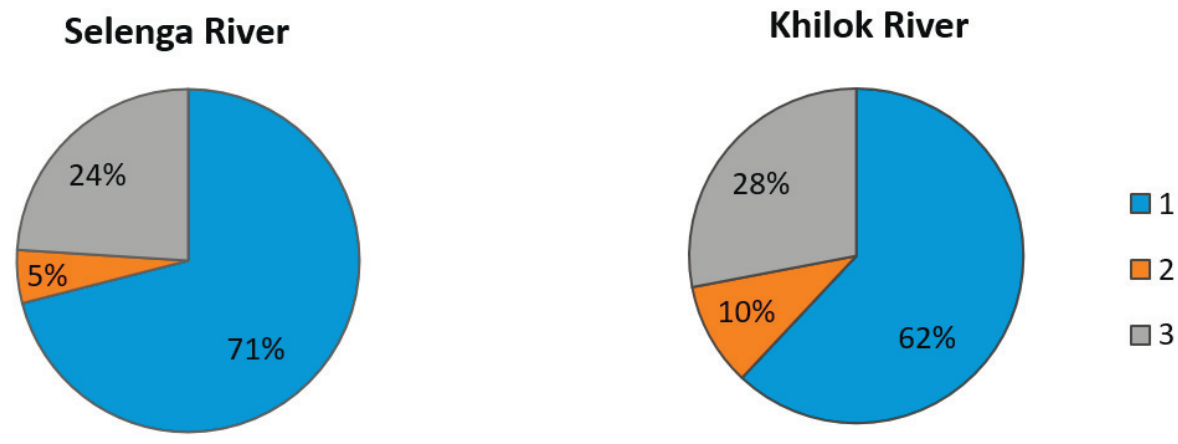

Fig. 1. Share of ice jam floods on the Selenga river: 1 - freshet; 2 - seasonal (snowmelt) flood; 3 ice jam flood.

Hazardous ice jams, which periodically cause economical damage, are marked at four sections of the Selenga River: 1) in the area of the Ganzurino settlement, 2) Kardon Saratovka - Voznesenovka settlements, 3) Mostovoy settlement - Gardeners' noncommercial partnership Kolos, 4) Tataurovo station - Ostrog settlement - Ilyinka settlement.

In the Ganzurino settlement the formation of ice jams occurs due to the tortuosity of the main channel and the presence of islands and braid bars. The territory of the settlement is located along the coastline, where the channel makes a rather sharp bend to the east and ice accumulations rest on the bedrock coast. The length of the hazardous area is about $1.2 \mathrm{~km}$.

The second section is quite long - over $14 \mathrm{~km}$. The river course is winding, heavily braided out with numerous islands and presents a rather complex system of arms and branches of various sizes, some of which are winding along the floodplain, forming quite sharp bends. As a result of expedition surveys and engineering materials of the Emergencies Ministry of the Republic of Buryatia seven potentially dangerous locations have been identified where ice accumulations and ice jams occur. In the settlement of Kolobki ice piles are pressed into the bedrock course. A bit higher near the settlement of Kardon ice jams are formed as a result of anthropogenic narrowing of the channel (railway 
bridge). The settlements of Kardon, Kolobki, Saratovka, Voznesenovka are under the threat of flooding.

In the area of Mostovaya passage, the Selenga river flows along a narrow valley, dividing the ridges. The course is straight, unbranched. The double-track railway crossing is an additional anthropogenic obstacle to ice drift. At the confluence of the Itanza River, Selenga abruptly changes (about $90^{\circ}$ ) its direction to the west, which limits the water flow and causes ice blocks accumulation. The settlements of Mostovoy, Pokrovka, Ilyinka, dacha settlement Kolos are at risk.

Calculations of physical risk indicators are based on hazard indices: repeatability, area of damage at design-basis water levels of a given exceedance probability. The repeatability rate of extreme events is determined on the basis of past ice jams and hydrological data on the selected Selenga River hydrological stations. The average probability is 0.05-0.2. However, each ice event occurs under certain conditions and largely depends on a range of factors for a particular water body section and the spring ice flow period.

The study revealed that the magnitude of the rain and freshet floods at the sites of ice jams formation (water outflow to the floodplain and flooding of coastal developed territories) is low, mainly up to $1.0 \mathrm{~m}$ due to the steep banks and high floodplains. Moreover, long-term observations show that the maximum values of the water level during ice jams in most cases exceed the maximum values of the level of extreme freshet floods (Fig. 2). For example, maximum level due to ice jams was registered at $613 \mathrm{~cm}$ (1977) at the Selenga-Mostovaya hydrological gauge, while maximum level of freshet amounted to $598 \mathrm{~cm}$ (1936). So for the period of 1934-2016, the flood of 1977 caused by ice jam is higher than the estimated freshet flood of $1 \%$ exceeding probability. For the remaining sections of the Selenga River, the maximum values of the water levels caused by ice jams correspond to the values of the freshet floods level of 3-5\% exceedance probability.

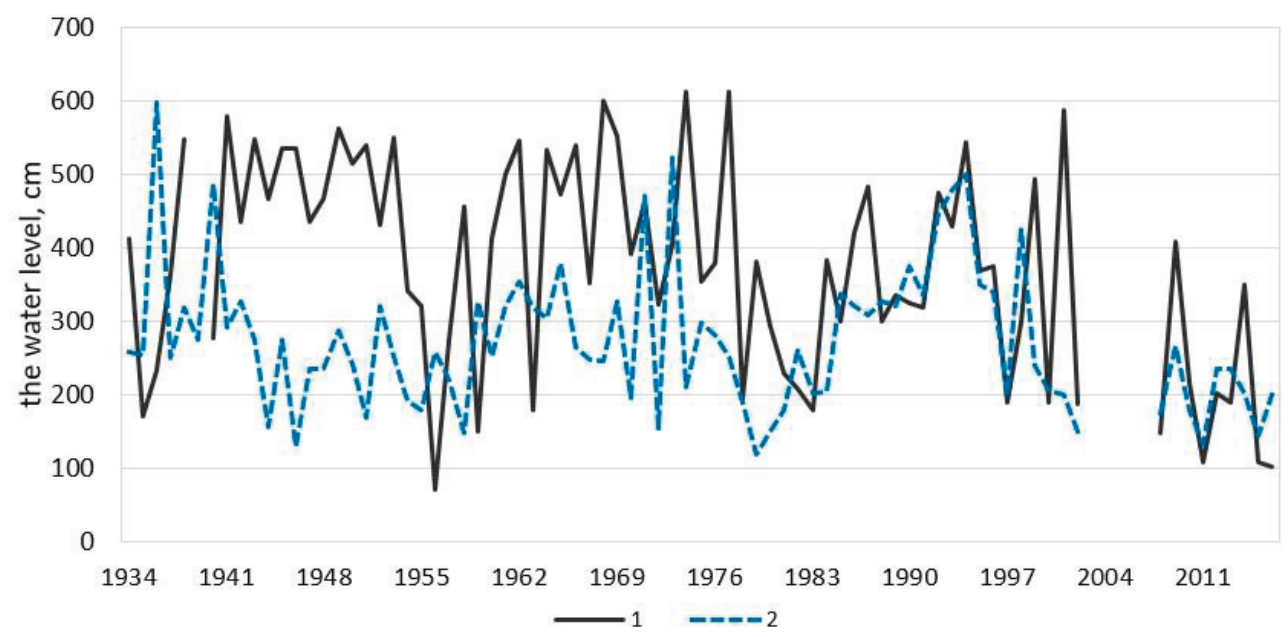

Fig. 2. The dynamics of maximum water level of the Selenga river (hydrological station Selenga razjezd Mostovoi): 1 -ice jams, 2 - freshet.

Identification of probable flood boundaries was carried out on the basis of large-scale topographic plans, orthophotoplans of high metric accuracy. Area determination was carried out using GIS technologies in ArcGIS software environment.

Approximately, the maximum flooding area of due to ice jams on the Selenga river is more than $10 \mathrm{~km}^{2}$, of which most are unused, vacant and agricultural land. For the agricultural industry, this type of flood does not cause any damage. Therefore, the zones of possible flooding are considered only within the boundaries of settlements. 
There are 9 settlements in the affected area. The area of settlements subject to flooding is more than 120 hectares. They accommodate 620 economic facilities, as well as two railway crossings and one highway bridge. The population of the settlements residing in hazardous zones is 3284 people. Calculations show that potential losses from a single occurrence reach over 1.9 billion rubles. Using the Flood Repeatability Index, the economic risk is determined. Thus, the annual damage may reach about 0.3 billion rubles.

\section{Conclusions}

In order to reduce the damage, an analysis of the possibilities to minimize the risks from the negative impact of ice jams was carried out. Primarily, engineering protection of settlements is proposed: the construction and reconstruction of 3 existing dikes and protection of banks in hazardous areas. However, the engineering system of flood protection supposes the injection of considerable financial resources, and not only those provided for construction, but also in the future for accident-free maintenance of hydraulic structures.

Currently, annually, ice is sawn down in dangerous areas to reduce the risks (mainly to protect bridges). Every year the Reserve Fund of the Republic of Buryatia for Prevention of Natural and Technogenic Emergency Situations allocates the funds. Thus, in 20193.5 million rubles have been allocated for sawing ice within the river network length of 34.5 $\mathrm{km}$. Calculations of economic efficiency show that it is generally expedient to carry out anti-jammimg measures. However, these volumes of ice-cutting operations do not reduce the frequency of ice jam floods and do not guarantee complete safety for all hazardous areas of the Selenga River. One of the alternative tools to reduce the risk of ice jam floods is to develop an economic mechanism. Introduction and development of the compulsory insurance system, development of tax benefits will allow reducing the financial burden on the state and providing financial guarantees to certain sectors of the economy and population in case of emergency.

The study was carried out under Project No. 18-45-030020 with the support of the Russian Foundation for Basic Research and the state assignment of the Baikal Institute of Nature Management SB RAS.

\section{References}

1. D.V. Kozlov, V.A. Buzin, N.L. Frolova., S.A. Agafonova, V.L. Baburin, L.S. Banshchikova, N.I. Goroshkova, A.S. Zavadsky, I.N. Krylenko, K.L. Savelyev, K.D. Kozlov, L.F. Buzina, Dangerous ice phenomena on the rivers and reservoirs of Russia (2015)

2. O.N. Potapov (Ed.), The hydrological regime of the river basin. Selenga and methods of its calculation (1977)

3. M.G. Vaskovsky (Ed.), Resources of surface waters of the USSR, 16, 3 (1973)

4. The State Water Cadastre. Long-term data on the regime and resources of land surface water, 1, 14 (1986)

5. A. Kauffeldt, F. Wetterhall, F. Pappenberger, P. Salamon, J. Thielen, Environmental Modelling \& Software, 75, 1 (2016)

6. K. Lindenschmidt, A. Das, P. Rokaya, T. Chu, Hydrol. Process., 30 (2016)

7. T.A. Borisova, Natural and anthropogenic risks in the lake basin. Baikal (2013)

8. A.N. Shpagina, S.Yu. Piterskaya, A.V. Fedorova, Methods of assessment of the probability of damage from adverse effects of water and evaluation of the effectiveness of preventive measures of water management (2006) 